\title{
Válvula Aórtica Cuadricúspide: Imágenes Intraoperatorias
}

Ricardo Zalaquett, Patricio González.

Sección Cirugía Cardiaca. Facultad de Medicina. Pontificia Universidad Católica de Chile.

Recientemente, Sepúlveda et al. publicaron en la Revista Chilena de Cardiología ${ }^{1}$ el caso clínico de una mujer de 60 años con una válvula aórtica cuadricúspide, diagnosticada por ecocardiografía transtorácica y transesofágica, no operada, con una extensa revisión de la literatura respectiva.
En esta oportunidad, nosotros presentamos los hallazgos intraoperatorios en un hombre de 72 años operado por una insuficiencia aórtica severa secundaria a una válvula aórtica cuadricúspide no diagnosticada preoperatoriamente.

\section{Quadricuspid aortic valve: intraoperative images}

Recently, Sepúlveda et al. published in Revista Chilena de Cardiología1 the clinical case of a 60-year-old woman with quadricuspid aortic valve diagnosed by transthoracic and transesophageal echocardiography not operated on, including an extensive review of the literature.

We present the intraoperative findings of a 72-year-old man with severe aortic insufficiency and a quadricuspide aortic valve, not preoperatively diagnosed. 
Figura 1. Válvula aórtica quadricúspide cerrada. Es posible observar los 4 pilares comisurales traccionados por puntos de seda negra.

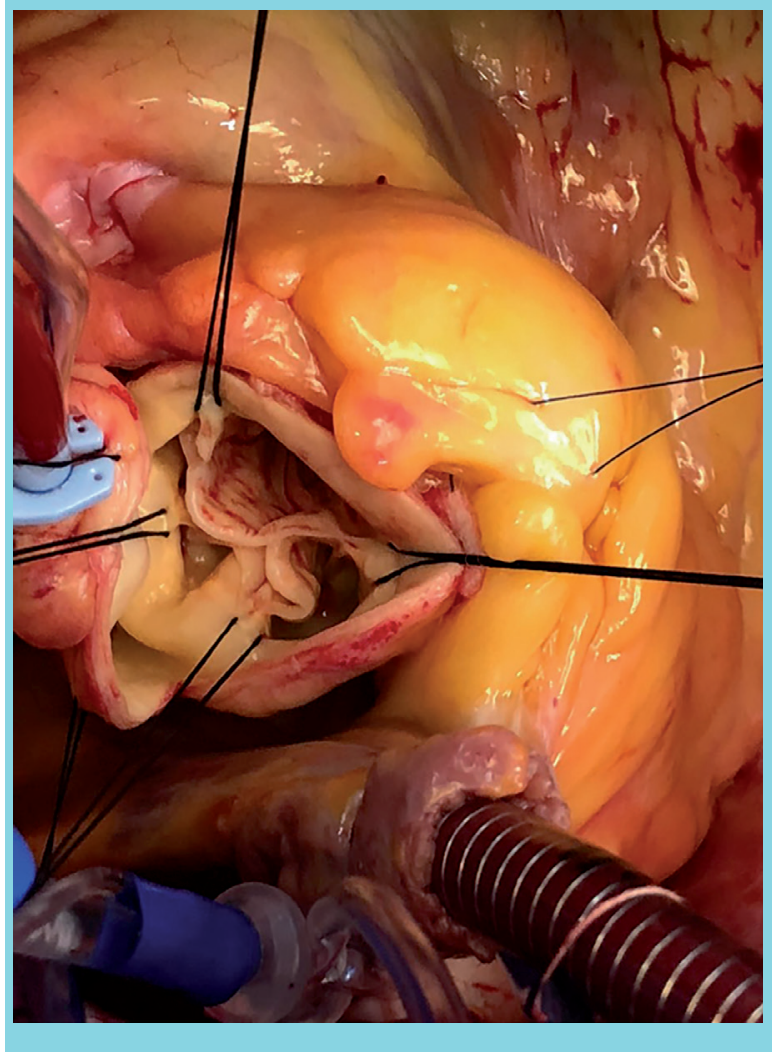

Figura 2. Válvula quadricúspide abierta. Es posible observar las cuatro comisuras valvulares aórticas.

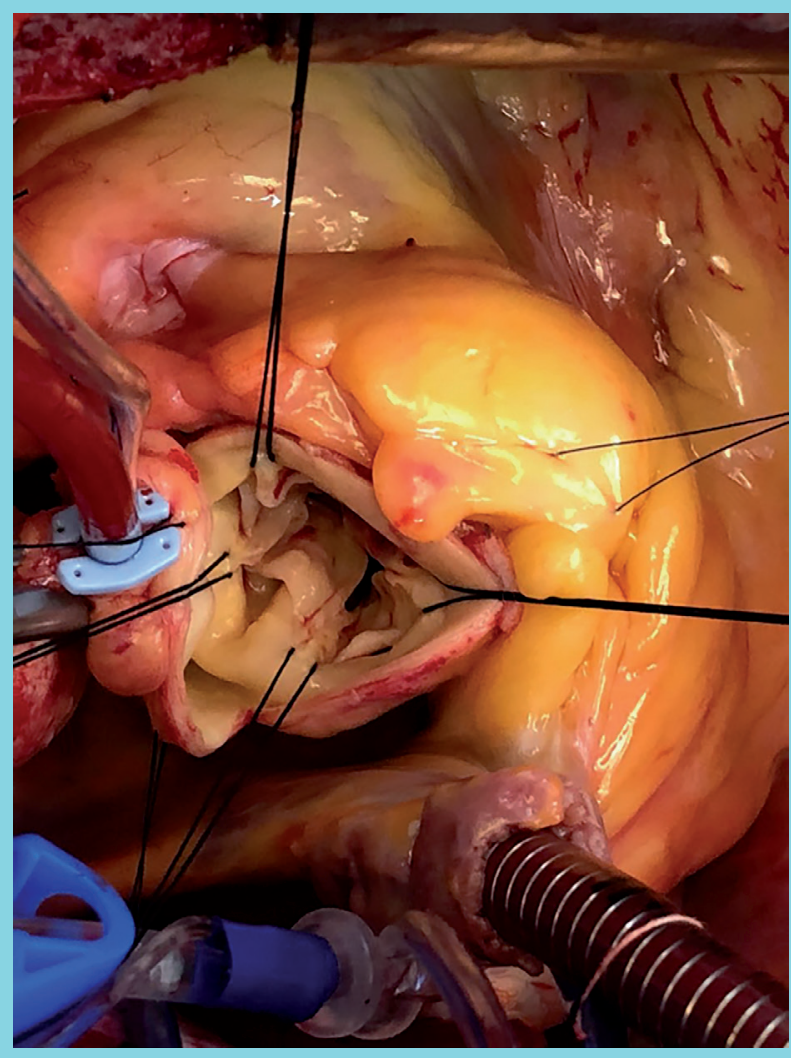

\section{Referencias}

1- SEPÚlVEDA J, TORRES J, LOPEZ L, DONOSO H, MICOLICH J. Válvula aórtica cuadricúspide: Caso clínico y discusión. Rev Chil Cardiol 2017; 36:122-126. 